\title{
ILMU PENGETAHUAN DAN TEKNOLOGI DALAM \\ REFORMASI BIROKRASI
}

Eliza Meiyani

Technology as media capable to reduce the potency of deviation in the service of state apparatus and action towards the development of corruption settlement (Collusion, corruption, and nepotisme), relating with the government commitment in the era of bureaucracy reformation to the implementation of good and clean government. Electronic government is the technology implementation in bureaucracy and the principles used in implementing the information technology for state task which well known with electronic government (e-government). Access optimalization towards information is the basic principle of transparency aiming to the use of technology in government.

Keywords : Technology as the government control equipment towards bureaucracy behavior

\section{Pendahuluan}

Sesuai dengan Inpres no 5

Tahun 2004, tentang percepatan pemberantasan KKN (Kolusi Korupsi dan Nepotisme), terdapat hal menarik yang menyangkut komitmen pemerintah untuk menggunakan Teknologi Informasi sebagai media yang dapat mengurangi potensi penyelewengan dalam pelayanan oleh aparatur negara dan tindakan korupsi. Hal tersebut menyiratkan adanya tekad untuk diadakannya reformasi terhadap birokrasi kita yang sudah terlanjur di cap sangat negatif oleh publik, sehubungan dengan pelayanan yang diberikan kepada publik dan banyaknya penyimpangan dalam proses kerjanya dengan menggunakan dan memanfaatkan teknologi. Mengapa memanfaatkan teknologi? Apakah birokrasi kita memang sudah siap dan sadar atas kemajuan Teknologi ? Apa yang haras dilakukan birokrasi untuk menuju penerapan eGovernment? Hal tersebut adalah pertanyaan yang sebenarnya harus dijawab untuk dapat menterjemahkan tujuan yang diharapkan sesuai dengan Inpres tersebut. Tetapi ada beberapa yang harus disimak oleh pemerintah dan unsur pelaksana di lapangan yang berhubungan dengan pemanfaatan Teknologi dan para perencana pengembangannya sehubungan dengan tujuan luhur dari pemerintah tersebut. 
tulisan ini akan membahas dan mengkaji pertanyaan untuk mengetahui apakah komitmen tersebut telah diiringi dengan kesiapan oleh aparatur apakah komitmen tersebut telah diiringi dengan kesiapan oleh aparatur Sumber Daya Manusia (SDM) dan masyarakat lainnya, serta faktor-faktor apa saja yang perlu mendapat perhatian untuk menuju birokrasi yang bersih dan bebas dari praktek Kolusi Korupsi Nepotisme (KKN) melalui Teknologi. Electronic Government merupakan penerapan teknologi dalam birokrasi kerangka dan prinsip-prinsip yang dipergunakan dalam penerapan Teknologi dan Informasi dalam lingkup pemerintahan dan tugas - tugas kenegaraan ini populer dikenal luas dengan nama electronic Government (eGovernment). Optimalisasi akses terhadap informasi inilah yang merupakan prinsip dasar dari transparansi yang dituju oleh penggunaan Teknologi di pemerintahan. Electronic-Government. menurut Instruksi Presiden RI nomor 3 tahun 2003 tentang Kebijakan dan Strategi Nasional Pengembangan EGovernment, merupakan proses transformasi dimana pemerintah mengoptimalkan pemanfaatan kemajuan teknologi serta informasi untuk mengeliminasi sekat-sekat birokrasi organisasi, serta membentuk jaringan sistem manajemen dan proses kerja yang memungkinkan instansiinstansi pemerintah bekerja secara terpadu untuk menyederhanakan akses dan transparansi ke semua informasi dan layanan publik yang harus disediakan oleh pemerintah. Dengan demikian seluruh lembaga-lembaga negara, masyarakat, dunia usaha, dan pihak-pihak berkepentingan lainnya dapat setiap saat memanfaatkan informasi dan layanan pemerintah secara optimal. Optimalisasi akses terhadap informasi inilah yang merupakan prinsip dasar dari transparansi yang dituju oleh penggunaan Teknologi di pemerintahan. Untuk selanjutnya dengan transparansi tersebut maka praktek Kolusi Korupsi Nepotisme (KKN) yang disebabkan oleh kekaburan informasi dapat diminimalkan. Selain tranparansi, yang ditawarkan oleh Teknologi, kata-kata kunci yang dapat dilihat dalam pernyataan tentang kegunaan e- 
Government diatas adalah bahwa egovernment diimplementasikan untuk dapat mengejar tujuan dalam hal: (1). Transformasi Pemerintah/birokrasi (2) Eliminasi sekat-sekat birokrasi (3) pembentukan jaringan sistem manajemen informasi (4) Perbaikan.

Hal - hal tersebut menjadi arah reformasi birokrasi dengan adanya pemanfaatan Teknologi yang optimal oleh pemerintah. Transformasi birokrasi yang ditawarkan dengan penerapan Teknologi dengan prinsipprinsip e-governmentnya adalah Teknologi diharapkan dapat merubah wajah birokrasi yang sudah ada dengan menawarkan pelimpahan tanggung jawab pihak-pihak pengelola pelayanan public yang biasanya berjumlah banyak sehingga sulit diawasi dan dimonitor kepada pihak yang lain yang lebih sedikit dan mudah untuk dimintai pertanggung jawabannya, karena sifat pihak tersebut yang sudah teruji kredibilitas dan profesionalitasnya. Hal tersebut bukan berarti bahwa proses kerja dan pelayanan publik hanya menjadi dilayani oleh lebih sedikit Sumberdaya Manusia SDM, tetapi lebih mengarah kepada adanya perubahan tata cara dan prosedur kerja yang berbeda dengan sebelumnya. ada pihak-pihak yang langsung menerima balas jasa uang ditangan mereka karena pelayanan yang diberikan, serta ada pihak yang memberikan hasil pelayanan langsung kepada masyarakat, tetapi dengan adanya Teknologi hal itu bisa dilewati atau dikurangi interaksinya. Sebab pada kenyataanya menurut Setiadi (Kompas, 16 Mei 2005), proses tatap muka akan menyebabkan peluang penyelewengan yang membuka kesepakatan untuk melakukan tindakan korupsi. Masyarakat, dengan adanya teknologi diharapkan tidak lagi perlu langsung menyerahkan uang sebagai biaya atas pelayanan yang diterimanya kepada pihak yang memberikan pelayanan. Hasil dari pelayanan tersebut bisa diterima tanpa ada/dikurangi interaksinya dengan si pemberi pelayanan. Sedangkan bagi sisi pemerintah, kemudahan didapat dengan semakin jelasnya pihak yang bertanggung jawab dalam pengoperasian sistem yang menggunakan system Teknologi, yang tentunya jumlah dan orangnya sudah jelas lebih sedikit dibanding sebelumnya. Transparansi akan lebih 
bisa dilihat oleh masyarakat karena syarat utama dari penggunaan Teknologi untuk proses kerja dan pelayanan publik adalah sudah adanya prosedur yang baku dan standar yang jelas. Apalagi, akan timbul kejelasan atas langkah - langkah apa yang harus dilakukan untuk pelayanan serta biaya yang harus dikeluarkan. Penggunaan dilakukan untuk pelayanan serta biaya yang hams dikeluarkan. Penggunaan serta penarikan biaya dari masyarakat bisa diawasi karena keterlibatan pihak lain yang lebih profesional dan kredibel dalam pengelolaan uang, seperti pihak bank, atau lembaga keuangan lainnya. Untuk mencapai dan menerapkan e-government tersebut perlu dilihat secara mendasar bagaimana seharusnya suatu organisasi pemerintah memulai menerapkan Teknologi sebagai media untuk pencapaian dan pelaksanaan Tupoksinya. Aplikasi Teknologi dalam e-government menawarkan suatu proses keg a yang bisa memotong antar fungsi organisasi (processes cut across organizational function) bahkan sampai ke ekstemal organisasi. Eliminasi sekat-sekat birokrasi perlu dilakukan agar kekakuan dalam penerapan TUPOKSI yang ada didalam birokrasi kita dapat dihindari. Aplikasi Teknologi dan Informasi dalam e-government menawarkan suatu proses kerja yang bisa memotong antar fungsi organisasi (cut across organizational function processes) bahkan sampai ke eksternal organisasi. Bisa saja divisi atau unit pengelola Teknologi ditempatkan pada fungsi tersendiri didalam organisasi, baik itu dtempatkan di bagian Sistem Informasi, Electronic Data Processing (bagian EDP) atau bagian umum sekalipun, tetapi secara proses, penerapan Teknologi seharusnya bisa memotong secara horizontal ke tiap bagian yang lain. Bagian Teknologi tidak hanya berfungsi menyuplai dan memelihara hardware dan software bagian-bagian lain tetapi lebih menjadi pengintegrasi setiap bagian yang ada di organisasi dan juga pihak di luar organisasi dengan menawarkan aplikasi antar fungsi (cross factions aplication). Strategi Cross function process dengan menggunakan Teknologi ini sudah menjadi bagian penting dari organisasi private yang melihat organisai tidak hanya dari segi fangsi tetapi lebih mengarah kepada 
sudut pandang proses. Strategi cross function proses manajemen yang ditawarkan oleh e-government dapat diperluas imtuk mencapai suatu jaringan sistem manajemen dan proses kerja yang memungkinkan instansiinstansi pemerintah bekerja secara terpadu. Beberapa pemerintah daerah telah melaksanakan pelayanan publik secara online dalam satu atap melalui satu portal sebagai bentuk pengintegrasian organisasi tersebut bahkan sudah melibatkan unit di instansi yang lain. Pendekatan yang sering disebut sebagai transparency process ini dilakukan dengan alasan bahwa masyarakat tidak perlu tahu proses pelayanan yang teijadi di dalam, atau masyarakat tidak dituntut untuk mengetahui instansi apa yang melayani kebutuhan mereka. Yang muncul di portal bukan nama - nama instansi tetapi daftar pelayanan. Sistem Informasi/Administrasi satu Atap (SIMTAP) seperti yang sudah diterapkan oleh beberapa instansi, seperti di Samsat, Pemprov Sulsel, Pemda Kabupaten Takalar (Sulawesi) dan Kutai (Kalimantan Timur), dan lainnya adalah contoh dari bentuk pelayanan online tersebut. Untuk selanjutnya TUPOKSI dari aparatur pemerintah harus ditambah dengan proses Integrasi (menjadi Tugas Pokok, Fungsi dan Integrasi). Sebagai wujud untuk merubah orientasi birokrasi kearah orientasi proses yang lebih mengarah nantinya kepada kelancaran proses kerja/manajemen dan orientasi pelayanan. Strategi lainnya yang tak kalah penting adalah berkaitan dengan membangun koordinasi intra dan antar-instansi pemerintah. Bila pada strategi pertama kita berbicara pada tataran integrasi proses dan teknologi, pada level di atasnya perlu dibangun strategi yang mendukung koordinasi intra dan antar instansi pemerintah, baik di level pemerintah pusat, pemerintah daerah, atau sesama pemerintah daerah. Dalam tata laksana pemerintahan yang konvensional hal ini sudah lama ada, namun pada kenyataannya masih sering ditemui adanya ketidak tersambungannya komunikasi antar satu dengan lainnya. Penyebab utama dari hal ini adalah masih rendahnya kualitas koordinasi antar-pihak yang seharusnya saling berinteraksi. Di dalam e-government, keberadaan koordinasi antar para pihak yang 
berkepentingan menjadi syarat utama dan manfaat keberhasilan pengimplementasiannya.

Teorltisasi Reformasi Birokrasi $=$ Business Process Reenginering (BPR) Sektor Publik Penerapan Teknologi memerlukan orientasi yang jelas dari organisasi untuk penggunaannya, sehingga Teknologi bukan menjadi beban biaya bagi organisasi tetapi merupakan media untuk memajukan dan memperlancar bisnis proses. Untuk mencapai suatu birokrasi yang dan memperlancar bisnis proses. Untuk mencapai suatu birokrasi yang terintegrasi melalui implementasi e-government ada beberapa hal yang hams dilihat dalam persiapan penerapannya. Seperti halnya praktek di sektor swasta, penerapan Teknologi dalam proses bisnis merupakan langkah strategis yang dituangkan secara khusus dalam strategic planning mereka. Penerapan Teknologi memerlukan orientasi yang jelas dari organisasi untuk penggunaannya, sehingga Teknologi bukan menjadi beban biaya bagi organisasi tetapi merupakan media untuk memajukan dan memperlancar bisnis proses. Caranya adalah dengan menjadikan Teknologi sebagai strategi perusahaan. Untuk itu di sektor swasta penerapan Teknologi merupakan hasil dari satu telaahan sistematis terhadap bisnis proses atau proses kerja yang kadang-kadang sangat radikal yang disebut dengan Business Process

Reengineering (BPR). BPR dapat didefinisikan sebagai "Pemikiran ulang secara fundamental dan pendesainan ulang secara radikal dari proses bisnis/kerja untuk mencapai kemajuan secara dramatis dalam ukuran-ukuran kritis dari kineija seperti biaya, kualitas, pelayanan, kecepatan" (Hutton, 1996).

Dari definisi di atas ada beberapa kata kunci yang hams diperhatikan, diantaranya adalah bahwa BPR merupakan suatu kegiatan yang: (1) fundamental yang mempertanyakan ulang hal-hal mendasar tentang organisasi dan bagaimana itu beroperasi; (2) radikal, dalam artian bahwa perubahan yang dilakukan itu bersifat ekstrim guna mendapatkan akar/sumber dari segala sesuatu dan menemukan secara komplet cara/jalan bam untuk melakukan kerja; (3) dramatis, berarti mencapai lompatan dalam kineija dan 
kemajuannya tidak sebagian-sebagian atau berkelanjutan. BPR diperlukan karena adanya kecenderungan pengakumulasian dari banyak aktifitas yang sudah tidak diperlukan lagi atau tidak lagi mempunyai nilai tambah kepada kegiatan organisasi Tujuan BPR yang utama adalah dicapainya suatu pencapaian/perbaikan kinerja dalam faktor-faktor kritis dari suatu organisasi, yaitu seperti biaya, kualitas, pelayanan maupun kecepatan. BPR diperlukan karena adanya kecenderungan pengakumulasian dari banyak aktifitas yang sudah tidak kegiatan organisasi, yang apabila tidak segera dilakukan perbaikan maka organisasi bisa tidak efisien dan efektif lagi, seperti yang terjadi di birokrasi kita. Kegunaan BPR sehubungan dengan penerapan Teknologi dan informasi juga sangat penting berkaitan dengan peranan dari Teknologi tersebut bagi organisasi. Kekuatan sebenarnya dari teknologi khususnya Teknologi Informasi adalah bukan membuat proses yang usang menjadi bekerja lebih cepat tetapi mampu membuat organisasi untuk merombak aturan lama dan menciptakan cara baru untuk mengoperasikan organisasi. Karena pada hakekatnya Organisasi (yang menggunakan pola) lama dengan teknologi baru hanya menjadi organisasi lama dengan biaya tinggi (old organization + New Technology $=$ Costly Old Organization). Jadi dengan prinsip-prinsip BPR, hendaknya organisasi menjadikan Teknologi sebagai sarana untuk memperbaharui pola kerja kearah yang lebih efektif dan efisien. Begitu pula halnya di sektor publik atau birokrasi, penerapan Teknologi seharusnya didahului suatu pendekatan strategis mengenai kegunaan maksimal dari Teknologi terhadap tujuan organisasi. Teknologi tidak bisa merubah organisasi tanpa kejelasan atas apa yang ingin dilakukan organisasi melalui Teknologi tersebut.

Rumusan Masalah yang harus dilakukan sebelum menggunakan Teknologi adalah "apa yang organisasi inginkan terhadap Teknologi dilakukan untuk organisasi? Bukan sebaliknya yaitu "apa yang dapat dilakukan teknologi untuk organisasi? Organisasi yang mengikuti pertanyaan “apa yang dapat Teknologi lakukan untuk organisasi? Dalam penerapan 
Teknologi selalu menggunakan Teknologi setiap mengetahui kelebihan dari suatu kemajuan di bidang Teknologi tanpa mengetahui "apakah itu akan berguna untuk organisasi atau tidak? Apakah organisasi dan Sumberdaya manusia SDMnya sudah siap menerima kemajuan tersebut? Contohnya, ketika teknologi Internet diterapkan dalam suatu organisasi, dan aplikasi e-mail tidak di optimalkan karena surat menyurat masih tetap dilakukan secara bentuk hard copy kepada bisnis relasinya. Atau masih memperlakukan e-mail sebagai surat, yang harus di print dan di file seperti surat tertulis biasanya, maka kegunaan yang harus di print dan di file seperti surat tertulis biasanya, maka kegunaan Teknologi Informasi tidak diperoleh secara optimal malahan menjadi tambahan beban biaya untuk organisasi. Berbeda dengan organisasi yang menjalankan pertanyaan“ apa yang organisasi ingin Teknologi lakukan untuk organisasi?. Ketika organisasi ingin dan bertujuan untuk mengurangi penggunaan media kertas dan biaya pos, maka organisasi mencari alternatif jawaban di bidang Teknologi tersebut yang bisa membantu mencapai tujuannya, yaitu penerapan total e-mail sebagai alat komunikasi dan kearsipan organisasinya. Ilustrasi diatas menunjukkan bahwa reformasi birokrasi merupakan Business Process Reengineering di sektor publik. Reformasi birokrasi merupakan langkah awal yang harus dilakukan sebelum kita menuju penerapan Teknologi dan Informasi untuk selanjutnya tercapainya manfaat egovernment. Bukan sebaliknya, bahwa dengan e-government akan tercapai tujuan reformasi birokrasi.

Untuk selanjutnya, proses reformasi birokrasi, untuk sampai dalam penerapan prinsip-prinsip egovernment, harus melakukan terlebih dahulu pengkajian ulang proses/manajemen kerja serta orientasi ulang birokrasi terhadap pelayanan publik. Menurat Hutton (1996: 26) BPR sangat relevan untuk merabah image birokrasi, menurutnya BPR akan dapat berperan untuk merabah cara kerja birokrasi yang berhubungan dengan pelayanan publik, transaksi yang melibatkan uang, penyimpanan record dan lain-lain. Hal ini menyangkut alasan dari pekerjaan 
tersebut yang bersifat mencari outcome dan memiliki kebebasan untuk menentukan bagaimana proses tersebut dikerjakan. Segala kegiatan di birokrasi yang sifatnya rutin, beralang dan dapat menggunakan pemrosesan berbasis Teknologi adalah mungkin untuk dilakukan BPR. Teknologi dan informasi sangat tinggi sekali potensinya untuk dipergunakan dalam kegiatan BPR. BPR atau dapat juga disebut Reformasi Birokrasi yang berbasis Teknologi bukan merupakan proses incremental atau perlahanlahan. Tindakan radikal dipergunakan untuk memperoleh nilai tambah yang sebenarnya dari penggunaan Teknologi. Reformasi ini merupakan tindakan yang signifikan untuk mencek kesehatan dari suatu organisasi dengan (SWOT), maupun faktor-faktor politik, ekonomi, sosial, dan teknologi. Selanjutnya, masih menurut Hutton, (1996: 27) ada beberapa Critical Success Factors (CSF) yang harus diterapkan dalam melakukan reformasi birokrasi atau BPR di sektor publik, yaitu: Keinginan untuk berubah dari status quo, ini berarti harus dilakukannya usahausaha untuk selalu mengeliminasi faktor-faktor yang resistant terhadap perubahan. Reformasi berarti bagaimana birokrasi harus merelakan tugasnya yang selama ini menjadi sapi perahan untuk keuntungan finansial dan sektoral menuju berorientasi pada kepentingan public : a) Memelihara komitmen, kesabaran dan keikutsertaan aktif dari top level selama pelaksanaan proses reformasi. Tanpa hal ini aktifitas reformasi hanya dapat menjadi program dalam kertas saja, b) Kejelasan dan kekonsistenan dari fokus stratejik dan visi jangka panjang dalam organisasi. c) Proses reformasi harus menjadi tujuan atau visi yang harus dicapai oleh birokrasi, d) Berorientasi pada tujuan, e) Memastikan dilakukannya perencanaan yang matang serta kemauan untuk mengalokasikan seluruh sumber daya yang ada, 1) Mengedepankan dialog yang berkelanjutan dengan seluruh stakeholder; Selalu dilakukannya pengukuran kinerja.

Semua hal diatas menunjukkan bahwa dalam proses reformasi dan birokrasi perlu dilakukannya usaha untuk memastikan kepada seluruh staf, pimpinan, masyarakat dan stakeholder 
tentang kepentingan dan keuntungan dari perubahan yang akan dilakukan. Kesalahan persepsi umum mengenai Teknologi dalam E-Government di Indonesia Diadaptasi dari Laudon \& Laudon 2000 Kalau melihat egovernment dari sudut pandang Sistem Informasi terdapat 3 (tiga) dimensi yang hams diperhatikan dalam usaha untuk mengimplementasikannya. Dimensi tersebut adalah: 1. Dimensi Teknologi Informasi 2. Dimensi SDM

\section{Dimensi Organisasi.}

Pembahasan Kesalahan dari pelaku dan birokrasi kita adalah dengan melihat e-government pada sudut pandang atau dimensi Teknologi Informasi saja. Sehingga yang tergambar kemudian adalah adanya kerumitan, biaya tinggi, resistensi dan perubahan pola kerja. Yang sebenarnya Teknologi Informasi dari prinsip perubahan pola kerja. Yang sebenarnya Teknologi Informasi dari prinsip e-Government merupakan puncak gunung es yang sering terlihat, tetapi kurang disadari bahwa ada bagian besar lain yang akan mempengaruhi berjalannya egovernment tersebut, yaitu dimensi Sumberdaya manusia SDM dan
Organisasi. Teknologi yang bentuknya bisa berupa Komputer, Internet, Jaringan, Satelit dan lain-lain, lebih sering muncul kepermukaan pada saat berbicara tentang e-government. Persepsi tersebut munculnya tidak hanya dalam pandangan masyarakat umum saja, tetapi juga menghinggapi para pengambil keputusan pemerintah kita. Contohnya bisa terlihat bahwa edaran Menpan, yang menganjurkan penerapan Teknologi secara optimal bagi aparatur pemerintah tidak diikuti dengan himbauan untuk meningkatkan kesadaran Teknologi dikalangan aparatur, adanya budaya sharing informasi dan pengorganisasian pengelolaan Teknologi dan Informasi dalam instansi pemerintah. Critical success factors lain dari penerapan egovernment seperti Sumberdaya Manusia SDM dan Organisasi sama sekali tidak menjadi perhatian penting. Sesuatu yang sangat bertolak belakang dengan apa yang dilakukan di negara yang sudah dinyatakan berhasil dalam penerapan-governmentnya. Penerapan e-government mereka canangkan setelah mereka rasa berhasil menciptakan birokrasi dan kultur organisasi yang siap dan mendukung 
penerapan e-government. Tak heran bahwa di negara seperti Singapura, pengendali utama dari penerapan egovernmentnya ada di Kementrian yang mengelola pegawai negeri (Civil Service), bukan ditangan Departemen yang mengelola teknologi Informasi dan Komunikasi. Kesalahan penilaian penerapan e-government hanya dari sudut pandang teknologi saja menghasilkan kesalahan persepsi yang lain dari birokrasi kita. E-governmen hanya dianggap sebagai proses pembuatan website saja tanpa mengelolanya dan memanfaatkannya secara maksimal (tahap lain setelah pemberian informasi, yaitu interaksi, transaksi dan data sharing). Menurut Pardo (2000:2), e-government tidak hanya menempatkan beberapa komputer atau membangun website untuk akses informasi, tetapi merupakan kegiatan mentransformasi hubungan fundamental antara pemerintah dan publik. Hubungan prinsip e-government.

Pemerintah harus selalu menanyakan secara terus menerus tentang tiga pertanyaan pokok berikut. 1) Apa fungsi yang menjadi tanggung jawab instansi pemerintah kita, 2)
Dapatkah kita mempertanggung jawabkan perubahan terhadap fungsi instansi kita ketika ada kemajuan teknologi bam yang kita terapkan 3) Apakah penerapan teknologi bam dalam instansi kita telah merefleksikan kebutuhan dan prioritas dari publik yang luas, atau malah dapat merusak kepercayaan publik.

Pertanyaan tersebut gagal dijawab oleh pemerintah kita dengan mengambil contoh dari penerapan Teknologi Informasi bagi kepentingan publik seperti halnya yang dilakukan KPU dengan pembangunan Sistem Informasi Perolehan Suara (tabulasi) Pemilu berbasis Teknologi Informasi. Pertanyaan tentang kegunaan sistem informasi yang dikembangkan oleh KPU telah menjadi kontroversi sehubungan dengan besarnya dana yang diserap dalam pengembangannya. Selain banyaknya kesalahan serta tidak siapnya operator dalam pengoperasiannya telah menimbulkan ketidakpercayaan publik. Manfaat yang didapat mesyarakatkan dari sistem tersebut dirasakan kurang sekali bahkan manfaat sistem dan teknologi tersebut dalam PILKADA sebagai satu 
rangkaian sistem PEMILU dari sistem demokrasi berasaskan pemilihan langsung dipertanyakan oleh masyarakat. Bagi Indonesia, yang memiliki karakteristik masyarakat dan tingkat penghidupan yang masih belum seperti yang diharapkan, adalah bijaksana apabila pembuatan suatu sistem yang menggunakan Teknologi Informasi untuk kepentingan publik dilakukan melalui perencanaan yang matang, apalagi itu menyangkut penggunaan dana yang tidak sedikit. Hendaknya usaha dilakukan pada titiktitik dimana itu benar-benar memberikan manfaat yang terbesar, seperti bagaimana usaha untuk mengurangi biaya penyediaan logistik, bukan pada usaha mempercepat pengumuman hasil pemilu seperti sekarang. Penggunaan Teknologi Informasi hams dilakukan untuk mendapatkan nilai tambah bukan untuk membuat proses kerja yang sudah usang (dan kurang menyentuh kepentingan publik) di buat lebih cepat (dengan adanya Teknologi). Teknologi dan Informasi harusnya ditempatkan (dengan adanya Teknologi). Teknologi dan Informasi harusnya ditempatkan pada peran sebagai pendobrak aturan lama dan menciptakan cara kerja yang baru yang lebih efisien dan efektif dan meningkatkan pelayanan kepada publik yang lebih luas.

Kesimpulan Seperti pengalaman negara-negara lain, penerapan teknologi dan Informasi dalam pemerintahan (e-government) bukan merupakan usaha yang mudah, diperlukan komitmen yang kuat dari pimpinan dan aparat birokrasi. Bila dihubungkan dengan usaha menggunakan e-government sebagai media untuk mengurangi potensi penyelewengan dalam pelayanan oleh aparatur negara dan korupsi, diperlukan suatu tindakan yang diluar kebiasaan (ekstrem) karena praktek praktek Kolusi Korupsi Nepotisme (KKN) di negara kita sudah merupakan tindakan atau penyelewengan yang extra-ordinary. Kontribusi dan penerapan Teknologi tidak akan signifikan selama pola-pola lama dalam proses kerja dan pelayanan kepada publik tidak dirubah. Proses kerja yang sudah usang yang disebabkan akumulasi dari proses kerja yang sudah tidak memberikan nilai tambah lagi terhadap efisiensi dan efektivitas organisasi, persepsi yang 
salah tentang penempatan reformasi birokrasi dalam kerangka egovernment, serta kesalahan penempatan e-government pada sudut Teknologi dan Informasi saja, telah mengurangi dan menghambat momentum perubahan yang diharapkan masyarakat terhadap birokrasi dan usaha mengurangi penyelewengan dan Kolusi Kompsi Nepotisme ( KKN).

\section{DAFTAR PUSTAKA}

Gronlund, Ake, (2002), Electronic Government: Design, Application and Management, Melbourne, Idea Group Publishing

Institute of System Science (2004), Use of Information Technology for Public Administration (Course handout), UNDP, Singpore Instruksi Presiden No. 5 Tahun 2004, tentang Percepatan

Pemberantasan KKN (Kolusi Korupsi dan Nepotisme) Instruksi Presiden RI Nomor 3 tahun 2003 tentang Kebijakan dan Strategi Nasional

Pengembangan E-Government Hutton, Graham, (1996), Business Process Reengineering A Public Sector View, Brisbane,
John Wiley \& Sons.

Laudon, Kenneth C, and Laudon Jane Price (1998), Information System and the Internet, A Problem Solving Approach, 4th Eds, Sydney, Dreyden Press 